\title{
$\checkmark$ Research Square \\ The Prevalence of Pathogenic Bacteria from Different Clinical Samples, Northern Part of Iraq.
}

ALLAA MIYASAR ( $\square$ alaa.20wed@gmail.com )

Research article

Keywords: Pathogenic Bacteria, Clinical Samples

Posted Date: July 8th, 2020

DOI: https://doi.org/10.21203/rs.3.rs-19354/v1

License: (9) (i) This work is licensed under a Creative Commons Attribution 4.0 International License. Read Full License 


\section{Abstract}

Background Bacteria are prokaryotic which causes a wide range of diseases in human and animals as well, thus, early diagnosis of bacterial infection is an important step for their management. The vast majority of bacteria are harmless to human and some strains are even beneficial. However, some strains cause infections including pneumonia, meningitis and urinary tract infection...etc. The present study aimed to describe and determine the prevalence rate of pathogenic bacteria in different clinical samples from Duhok city, Kurdistan region of Iraq, as there are no available data of bacterial infections.

Methods Totally, 200 adult patients enrolled in the present study during July 2017-July 2018. We collected different clinical specimens including (SFA, Bronchial Lavage, catheter, cerebrospinal fluid, body fluids, blood, semen, stool pus, urine, sputum and ear swabs). Standard microbiological techniques used for isolation and identification. All samples collected before antibiotic uses by specialized physician.

Results The result reported that forty-six samples (23\%) obtained from male and one hundred fifty-four samples $(77 \%)$ obtained from females. A high diversity of pathogens was found but Staphylococcus aureus recorded the highest infection rate by (33.3\%) which observed in 32 urine samples by and followed by E. coli (27.3\%) and Coagulase-Negative Staphylococci (25.3\%), which observed in 36 and 29 urine samples, respectively. Alternatively, Klebsiella, Streptococcus, Enterobacteriaceae and Pseudomonas aeruginosa were founded in few samples.

Conclusion The highest diversity of potential pathogens observed in urine samples was E.coi. Over all, Staphlococcus aureus was predominant and recorded the highest prevalence rate by (33.3\%) in 50 samples which followed by E. coli recorded in 41 samples (27.3\%) and Coagulase-Negative Staphylococci observed in 38 samples (25.3\%).

\section{Background}

The isolation of microorganism is an important step in diagnosis and analyses of microbial virulence (1). Additionally, isolation and culturing enable the investigation of antibiotic sensitivity for selecting the best effective treatment $(2,3)$, genome sequencing $(4,5)$ and disease diagnosis $(6)$. Robert Koch, proposed that a pure culture is the foundation of all research in case of infectious diseases $(7,8,9)$.

Recently, many researches attempt in determining the common pathogenic bacteria and normal flora which cause diseases in human. Staphlococcus aureus, Escherichia coli and Streptococcus sp. have been widely studied due to their drug resistance and diverse pathogenic features (10) and (12).

The present study aimed to determine and list the bacterial prevalence in different human samples from Duhok city - Kurdiastan region of Iraq, for this purpose statistical analysis performed for easy data analysis.

\section{Methods}




\section{Sample collection}

Totally, 200 adult patients enrolled in the present study during July 2017- July 2018. Different clinical specimens collected depend on patient symptoms including SFA, Bronchial Lavage, catheter, (cerebrospinal fluid) CSF, body fluids, blood, semen, stool pus, urine, sputum and swabs from ear, throat and eyes. All samples collected before antibiotic uses by specialized physician.

\section{Isolation and Identification}

Diagnosis of bacterial isolated conducted with the aid of standard microbiological techniques and collected data were analyzed using SPSS stastical software (SPSS 25.0, 2017), for easy data expression, $p$ value was $P<0.05$. The swabs were streaked onto nutrient agar, blood agar, MacConkey agar, Mannitol salt agar and Chocolate agar plates in two replications for minimizing the rate of contamination. The inoculated plates were incubated separately in two group of aerobic and anaerobic conditions for 20-24 hours at $37^{\circ} \mathrm{C}(13)$. Bacterial isolates defined by observing colony morphology, pattern and size. However, Gram staining techniques used for subgrouping the colonies into Gram negative and Gram positive groups. Additionally, the process of identification further confirmed by biochemical studies which included IMViC test, oxidase test, catalase test, coagulase test and urease test.

\section{Results}

During 2017-2018, a total of 200 samples obtained from suspected patients from Dhuok city for bacterial infections. All samples were isolated and identification conducted with standard microbiological techniques. The result reported that forty-six samples (23\%) obtained from male and one hundred fiftyfour samples $(77 \%)$ obtained from females, also result declared that bacterial growth were positive for 106 samples (53\%) while no bacterial growth observed from the reset 94 samples as shown in Table 1.

The frequency of collected samples listed according to the type of specimens as shown in Table 2. The most collected samples were urine in which 144 urine samples collected and followed by vagina, pus, sputum, blood and swabs samples by 14, 11, 9, 7 and 6 respectively. However, collected samples were at low percentage for CSF, SFA, wound, fluid, catheter and bronchial lavage .

The highest frequency rate of bacterial isolate recorded in 79 urine samples (39.5\%) and followed by 6 vagina samples and 5 sputum samples, by (3\%) and (2.5\%), respectively. Notably, few bacterial growths observed in samples such as blood and CSF by $1.5 \%$ and $1 \%$, respectively. However, bacterial growth observed only in one sample of (swab, SFA, catheter, fluid, wound and bronchial lavage) by $0.5 \%$, as shown in Table 3.

The prevalence rates of bacterial isolates have been listed according to the type of specimens as shown in Table 4. The result determined that Staphlococcus aureus recorded the highest infection rate by (33.3\%) in 50 samples and observed in 32 urine samples. E. coli recorded second highest prevalence rate 
by (27.3\%) which observed in 36 urine samples and followed by Coagulase-Negative Staphylococci which recorded in by $(25.3 \%)$ and observed in 29 urine samples.

Alternatively, Klebsiella, Streptococcus, Enterobacteriaceae and Pseudomonas aeruginosa were founded in 9,8,3 and 1 samples, respectively. The percentage of bacterial infection in the present study has been shown in Figure 1.

\section{Discussion}

According to the present study, 106 collected samples showed positive bacterial growth out of 200 samples in which 74 positive samples were collected from female and only 32 positive samples were from male. This finding is in line with previous finding which reported that male was more resistance to gastrointestinal and respiratory tract bacterial infections, while female was more prone to bacterial infections in the genitourinary tract same investigation also declared that such differences for bacterial susceptibility between male and female associated to the sex hormones (13).

From the present study, highest frequency rate of bacteria isolated from urine samples by $(39.5 \%)$ and followed by vagina and sputum by $(3 \%)$ and $(2.5 \%)$, respectively. This result totally agrees with previous finding by, Flores-Mireles and et al. (2015), who considered urinary tract infections (UTIs) as the most common bacterial infections at all ages which affecting around 150 million people worldwide per each year and causes morbidity as well (14). Additionally, vaginal infection considered as the second most common bacterial infection in women which called bacterial vaginosis (BV) and characterized by pyogenic infection (15) and (16). Pus producing infection called pyogenic, Staphylococcus aureus and Streptococcus pyogenes are the best known microorganisms which cause pus due to the secretion of toxins which damage neutrophil and surrounding tissue (17). Pseudomonas, Staphlococcus aureus, and Burkholderia cepacia complex identified as the most frequently isolated bacteria from the sputum of patients with chronic chest lesions or pulmonary disease (18), this finding is agree with our finding in which the number of infections were 9 samples. Only 3 blood samples showed positive bacterial growth, the presence of bacteria in the blood is known as bacteremia which has several significant health consequences. (18), bacteria may also spread through the blood to other parts of the body and causes infection away from the original infection site. (19), (20),(21) and (22). Low number of bacterial growth recorded in ear swabs, CSF, SFA, catheter, fluid, wound and bronchial lavage samples. These results agree with many previous published studies which recorded that approximately 65-330 million people worldwide suffer from ear infection and $60 \%$ have serious hearing impairment $(23,24)$, the sperm cell structure and the whole spermatogenetic cycle can be affected by acute and chronic infections system $(25,26,27,28)$. Bacteria can cause wound infection in case of skin defective functions $(29,30)$, however, wound infection could be a type of nosocomial infection (31).

Staphlococcus aureus, a Gram-positive bacterium which causes a wide range of infectious diseases, including skin infections, bacteraemia, endocarditis, pneumonia and food poisoning (32), the result determined that Staphlococcus aureus recorded the highest infection rate by (33.3\%). E. coli, a normal 
flora in the intestinal lumen of human which maintaining normal intestinal homeostasis $(16,33)$. Some strains of $E$. coli varieties may diverge and causes diseases, such strains acquire unique virulence factors by which causes infections (34). Klebsiella pneumoniae, accounts as a significant proportion of hospitalacquired infections of the urinary tract, pneumonia, septisemia, and soft tissue (35). In the present study Klebsiella pneumoniae represented in 9 patient samples (6\%), while Streptococcus spp. was represented in 8 patient specimens (5.3\%). Enterobacteriaceae only observed in urine samples, this result in agreement with previous finding in which concluded that members of Enterobacteriaceae causes urinary tract infections (UTI) and diarrhea (35). Pseudomonas aeruginosa, a Gram-negative bacillus which causes hospital acquired infections more commonly in patients with ventilation, burn patients, and chronic debility patients (36), the growth of this bacteria only reported in one sample.

\section{Conclusion}

Staphlococcus aureus recorded the highest prevalence rate by (33.3\%) and observed in all samples except swabs. While E. coli recorded in 41 samples $(27.3 \%)$ and followed by Coagulase-Negative Staphylococci which observed in 38 samples (25.3\%). Additionally, highest bacterial growth reported in urine samples, this finding needs further investigation like antibiotic sensitivity profile study for selecting effective treatment.

\section{Abbreviations}

SFA specimens

Semin fluid analysis specimens, CSF = Cerebrospinal fluid specimens, $S$. aureus = Staphlococcus aureus, E. coli $=$ Escherichia coli, $\mathrm{UTI}=$ Urinary tract infection, $\mathrm{BV}=$ bacterial vaginosis, $\mathrm{SSTI}=\mathrm{Skin}$ and Soft tissue . CoNS = Coagulase-Negative Staphylococc

\section{Declarations}

Ethics approval and consent to participate: the proposal of the study approved by Scientific Committee of College of Health Science /Hawler Medical University. Informed consent was taken from all study participants.

\section{Consent of publication}

The present study not includes details, images or videos relating to individual participants, thus consent for publication were not required.

\section{Availability of data and materials}

The author confirms that the data supporting the findings of this study are available within the article.

\section{Competing interests}


the author declared that she has no competing interests.

\section{Funding}

Not applicable.

\section{Authors' contributions}

Allaa M. Ahmed, the only author performed research, read and approved the final manuscript.

\section{Acknowledgements}

I would like to thank academic staff of Hawler Medical University, for their support.

\section{References}

1. Marshall BJ, Armstrong JA, McGechie DB and Glancy, RJ. Attempt to fulfil Koch's postulates for pyloric Campylobacter. Med J Aust. 1985; 142:436-439.

2. Boulos A, Rolain JM, Mallet MN, Raoult D. Molecular evaluation of antibiotic susceptibility of Tropheryma whipplei in axenic medium. J Antimicrob Chemother. 2005; 55:178-181. doi:10.1093/jac/dkh524.

3. Boulos A, Rolain JM, Raoult D. Antibiotic susceptibility of Tropheryma whipplei in MRC5 cells. Antimicrob Agents Chemother. 2004; 48:747-752. doi:10.1128/AAC.48.3.747-752.2004.

4. Fournier $P E$, Drancourt $M$, Raoult $D$. Bacterial genome sequencing and its use in infectious diseases. Lancet Infect Dis. 2007; 7:711-723. doi:10.1016/S1473-3099(07)70260-8.

5. Raoult D, Ogata H, Audic S, Robert C, Suhre K, Drancourt M and Claverie JM. Tropheryma whipplei Twist: a human pathogenic Actinobacteria with a reduced genome. Genome Res. 2003; 13:18001809.

6. Simranjit K, and Prashant Ch. Isolation and Characetrisation of Pathogens from Various Clinical Samples: A Step towards Prevention of Infectious Diseases. JPSBR. 2015; Volume 5. Issue 4: (404409).

7. Lagier J-Ch, Edouard S, Pagnier I, Mediannikov O, Drancourt M and Raoult D. Current and Past Strategies for Bacterial Culture in Clinical Microbiology. Clinical Microbiology Reviews. 2015; Volume 28. Number 1.

8. Brock T, Robert Koch: a life in medicine and bacteriology. American Society for Microbiology, Washington, DC. 1999.

9. Koch R. Die Äetiologie der Tuberkulose. Berl Klin Wochenschr. 1882; 15:221-230.

10. Begum R, Towhid ST, Moniruzzaman M, Mia Z and Islam MA. Study of Staphlococcus aureus from Clinical Samples in Savar, Bangladesh. Research Journal of Microbiology. 2011; Volume 6 (12): 884890. 
11. Brooks GF, Butel JS, Morse, SA. and Jawetz, E. Melnick and Adelberg's. Medical Microbiology. 2001; 22nd Edn., Appleton and Lange, New York, USA., ISBN-13: 9780838562987, Pages: 694.

12. Trepeta RW, and Edberg SC. MethylumbelliferyI-D-Glucuronide-Based Medium for Rapid Isolation and Identification of Escherichia coli. JOURNAL OF CLINICAL MICROBIOLOGY. 1984; Vol. 19, No. 2. p. 172-174.

13. Vázquez-Martínez ER, García-Gómez E. and Camacho-Arroyo I. Sexual dimorphism in bacterial infections. Biol Sex Differ. 2018; Vol. 9: Pages: 27.

14. Flores-Mireles AL, Walker JN, Caparon M and Hultgren SJ. Urinary tract infections: epidemiology, mechanisms of infection and treatment options. 2016; Vol; 13(5): Pages: 269-284.

15. Streptococcus pneumoniae - Pneumococcal Disease. 2019. Arupconsult. https://arupconsult.com/content/streptococcus-pneumoniae .

16. Alexander FM. Wound Infection: Nursing Practice Hospital and Home, the Adult. New York: Churchill Livingstone; 1994.

17. Schulman J S. Everything You Need to Know About Pus. https://www.healthline.com/health/pus. 2018.

18. Vázquez-Martínez ER, García-Gómez E, Camacho-Arroyo I and González-Pedrajo B. Sexual dimorphism in bacterial infections. Biol Sex Differ. 2018; 9: 27.

19. Brazier Y. What is bacterial vaginosis?. Medical News Today. 2017. University of Illinois-Chicago, School of Medicine.

20. Roy S and Dhar D. Isolation, Characterization and Antibiotic Sensitivity Pattern of Different Bacteria in Pus Sample. 2018. Journal Metrics.

21. Moniema AN and Amin NM. Bacteria in sputum of patients with chronic chest lesions in chest department of Beni-Suef University Hospital. Egyptian Journal of Chest Diseases and Tuberculosis. 2016. Volume 65, Issue 4, Pages 841-8.

22. Shu-Ling F, Miller, Nancy S, Lee, John, Remick, Daniel G. (2016-09-01). "Diagnosing sepsis - The role of laboratory medicine". Clinica Chimica Acta; International Journal of Clinical Chemistry. 460: 203210. doi:10.1016/j.cca.2016.07.002. ISSN 1873-3492. PMC 4980259. PMID 27387712.

23. Sule A, Thanin L, Sule Odu O, Olusonya O. Bacterial pathogens associated with infected wounds in Oguo State University teaching Hospital, Sagon, Nigeria. Afr J Clin Exp Microbiol. 2002;3:13-6.

24. Fatemaa, K, Mondolb K, Akterc T and Dattad S. Detection of Pus Sample of Various Pyogenic Infections from Diabetic and Non Diabetic Patient and Compare their Socioeconomic Status in Bangladesh. American Scientific Research Journal for Engineering, Technology, and Sciences (ASRJETS). 2016; Volume 26, No 1, pp 159-165.

25. Moretti E, Federico M G, Giannerini V, Capitani S, Collodel G, Pammolli A. and Figura N. The presence of bacteria species in semen and sperm quality. J Assist Reprod Genet. 2009 Jan; 26(1): 47-56.

26. Henkel R. and Schill WB. Sperm separation in patients with urogenital infections. Andrologia 1998; 30:91-7. 
27. Urata K, Narahara H, Tanaka Y. Egashira T, Takayama F. and Miyakawa I. Effect of endotoxin-induced reactive oxygen species on sperm motility. Fertil Steril. 2001; 76:163-6. doi:10.1016/S00150282(01)01850-7.

28. Sanocka-Maciejewska D, Ciupińska M. and Kurpisz, M. Bacterial infection and semen quality. J Reprod Immunol. 2005; 67:51-6. doi:10.1016/j.jri.2005.06.003.

29. Kaper JB, Nataro JP and Mobley HL. Pathogenic Escherichia coli.. Nat Rev Microbiol. 2004; 2(2):12340.

30. Perez-Chaparro PJ, Meuric V, De Mello G, Bonnaure-Mallet M. "[Bacteremia of oral origin]". Revue de Stomatologie et de Chirurgie Maxillo-Faciale. 2011; 112 (5): 300-303.

doi:10.1016/j.stomax.2011.08.012. ISSN 1776-257X. PMID 21940028.

31. Dionigi R, Rovera F, Dionigi G, Imperatori A, Ferrari A, Dionigi P. and Dominioni L. Risk factors in surgery. J Chemother 2001; Spec No 1(1): 6-11

32. Bowler P, Duerden I. and Armstrong D. Wound microbiology and associated approaches to wound management. Clin Microbiol Rev. 2001; 14(2): 244-269

33. Dionigi R, Rovera F, Dionigi G, Imperatori A, Ferrari A, Dionigi P, et al. Risk factors in surgery. J Chemother. 2001;13:6-11.

34. Helen S, Lee, Pharm, D. BCPS-AQ ID. and Jennifer, Le. Urinary Tract Infections. Infectious Diseases. 2015.

35. Kaper JB, Nataro JP and Mobley HL. Pathogenic Escherichia coli.. Nat Rev Microbiol. 2004; 2(2):12340.

36. Rachel and Murrell D. Coagulase-Negative Staph Infection.

https://www.healthline.com/health/coagulase-negative-staph.

\section{Tables}

Table (1): Distribution of bacterial infection according to the sex of suspected patients.

\begin{tabular}{|l|l|l|l|}
\hline Number of & Samples & Infections & No Growth \\
\hline Male & $46(23 \%)$ & $32(16 \%)$ & $14(7 \%)$ \\
\hline Female & $154(77 \%)$ & $74(37 \%)$ & $80(40 \%)$ \\
\hline Total & $200(100 \%)$ & $106(53 \%)$ & $94(47 \%)$ \\
\hline
\end{tabular}

Table (2): Frequency and percentage of collected samples according to the type of specimens 


\begin{tabular}{|l|l|l|l|}
\hline Source of infection & Number (\%) & Source of infection & Number (\%) \\
\hline Urine & $144(72 \%)$ & CSF & $3(1.5 \%)$ \\
\hline Vagina & $14(7 \%)$ & SFA & $2(1 \%)$ \\
\hline Pus & $11(5.5 \%)$ & Wound & $1(0.5 \%)$ \\
\hline Sputum & $9(4.5 \%)$ & Fluid & $1(0.5 \%)$ \\
\hline Blood & $7(3.5 \%)$ & Catheter & $1(0.5 \%)$ \\
\hline Swabs & $6(3 \%)$ & Bronchial Lavage & $1(0.5 \%)$ \\
\hline Total & $200(100 \%)$ & \\
\hline
\end{tabular}

Table (3): Frequency rate of bacterial growth according to the type of samples.

\begin{tabular}{|c|c|c|c|c|c|}
\hline $\begin{array}{l}\text { Source of } \\
\text { infection }\end{array}$ & $\begin{array}{l}\text { Infected with } \\
\text { Bacteria }\end{array}$ & No Growth & $\begin{array}{ll}\text { Source } & \text { of } \\
\text { infection } & \end{array}$ & $\begin{array}{l}\text { Infected with } \\
\text { Bacteria }\end{array}$ & No Growth \\
\hline Urine & $79(39.5 \%)$ & $65(32.5 \%)$ & $\mathrm{CSF}$ & $2(1 \%)$ & $1(0.5 \%)$ \\
\hline Vagina & $6(3 \%)$ & $8(4 \%)$ & SFA & $1(0.5 \%)$ & $1(0.5 \%)$ \\
\hline Sputum & $5(2.5 \%)$ & $4(2 \%)$ & Catheter & $1(0.5 \%)$ & 0 \\
\hline Pus & $4(2 \%)$ & $7(3.5 \%)$ & Fluid & $1(0.5 \%)$ & 0 \\
\hline Blood & $3(1.5 \%)$ & $4(2 \%)$ & Wound & $1(0.5 \%)$ & 0 \\
\hline Swab & $1(0.5 \%)$ & 5) $2.5 \%)$ & Bronchial Lavage & $1(0.5 \%)$ & 0 \\
\hline
\end{tabular}

Table (4): Prevalence rate of different bacterial isolates from different samples

\begin{tabular}{|c|c|c|c|c|c|c|c|}
\hline $\begin{array}{l}\text { Source of } \\
\text { infection }\end{array}$ & $\begin{array}{l}\text { Staphloco-ccus } \\
\text { aureus }\end{array}$ & E. coli & $\begin{array}{l}\text { Coagulase- } \\
\text { Negative } \\
\text { Staphylococci }\end{array}$ & Klebsiella & $\begin{array}{l}\text { Strepto- } \\
\text { coccus }\end{array}$ & Enterobacteriaceae & $\begin{array}{l}\text { Pseudo- } \\
\text { monas }\end{array}$ \\
\hline Urine & 32 & 36 & 29 & 8 & 4 & 3 & 0 \\
\hline Vagina & 2 & 2 & 3 & 1 & 1 & 0 & 0 \\
\hline Pus & 2 & 1 & 2 & 0 & 1 & 0 & 1 \\
\hline Sputum & 3 & 1 & 1 & 0 & 2 & 0 & 0 \\
\hline Swab & 0 & 0 & 1 & 0 & 0 & 0 & 0 \\
\hline SFA & 1 & 0 & 1 & 0 & 0 & 0 & 0 \\
\hline $\begin{array}{l}\text { Bronchia } \\
\text { lavage }\end{array}$ & 1 & 0 & 0 & 0 & 0 & 0 & 0 \\
\hline Catheter & 1 & 0 & 0 & 0 & 0 & 0 & 0 \\
\hline $\mathrm{CSF}$ & 2 & 0 & 1 & 0 & 0 & 0 & 0 \\
\hline Blood & 2 & 1 & 0 & 0 & 0 & 0 & 0 \\
\hline Fluid & 1 & 0 & 0 & 0 & 0 & 0 & 0 \\
\hline Wound & 1 & 0 & 0 & 0 & 0 & 0 & 0 \\
\hline Total & 50 (33.3\%) & $41(27.3 \%)$ & $38(25.3 \%)$ & $9(6 \%)$ & $\begin{array}{l}8 \\
(5.3 \%)\end{array}$ & $3(2 \%)$ & $\begin{array}{l}1 \\
(0.7 \%)\end{array}$ \\
\hline
\end{tabular}


Figures

\section{Infection propotion}

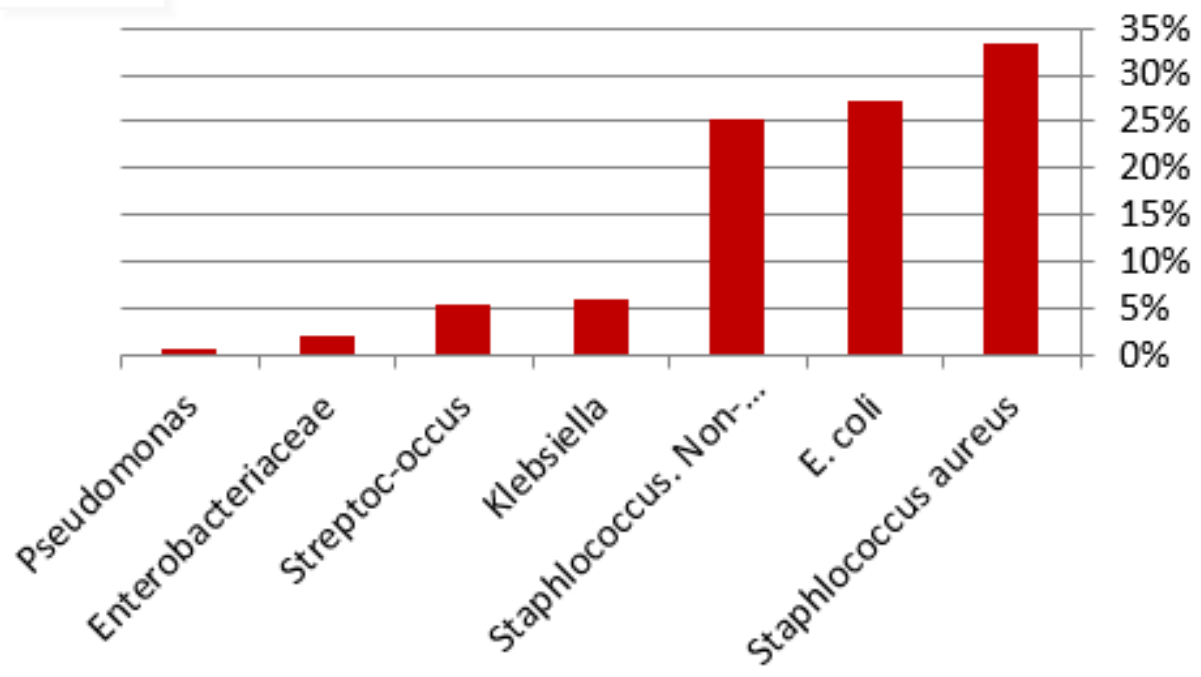

Figure 1

Percentage of bacterial isolates and infection proportion 